\title{
WOMAN'S PLACE IN INDUSTRY AND LABOR ORGANIZATIONS
}

This paper is about one-fourth of an unpublished monograph dealing in a comprehensive way with "The Effects of the Industrial Organization of Society on the Status of Woman." TTHE EDTTOR.

\section{Woman's Status in the Past.}

Woman's status throughout the civilized world is different now from what it has been. This difference is not due to the special physical or mental merits suddenly discovered in her. And it is not because of her so-called increased industrial activity. From time immemorial woman has been an industrial producer. We have no accounts of the battles she has fought and won, no record of her inventions, discoveries or creation of new ideas and ideals, but nearly every parent industry calls her mother. As far as primitive history can be reconstructed, it was she who originated and fostered the peaceful arts of life. She it was who discovered the ability of labor. She, "the slave before the slave existed," laid the foundation of civilization, but, as regards her present industrial contributions, she compares most unfavorably with woman of old. In savage or barbarian society as food-bringer, weaver, skin-dresser, potter and burden-bearer, she was the acknowledged economic factor. In the words of a Chippawayan chief, "Women are made to labor, one of them can carry or haul as much as two men can do. They also pitch our tents, make and mend our clothing $* * *$ and in fact, there is no such thing as traveling any considerable distance in this country without their assistance." 1

In Greece and Rome woman's function as slave or supervisor of slaves was generally recognized. This is true all through the Mediæval Ages. "Her duties were so manifold that a conscientious housewife had to be at her post from early in the morning till late at night to fulfill them, and even then it was only possible to do so with the help of her daughters. $* * *$ She had to spin, weave and bleach, to make all the linen and clothes, to boil soap and make candles and brew beer. In addition to these occupations she fre-

1 Spencer. "Principles of Sociology," vol. ii, p. 727.

[343] 
quently had to work in the fields and the garden and to attend to the poultry and cattle. In short, she was a veritable Cinderella, and her solitary recreation was going to church on Sunday."2

While woman's labor was thus very much in demand hitherto, at present, when organized industry displaces domestic work, men would only be too glad to do away with her industrial activity altogether. They claim the ability to produce all the necessaries of life conducive even to a higher standard of living than is possible at a time when women competitors crowd the factories, shops, offices, schools, and so forth.

Woman's present status is not due to her increased physical, mental or industrial importance as compared with that of man. Is it due to his increased chivalry, charity, generosity, liberality or effeminacy? Perhaps. But the majority of men, whom we cannot by any means deny to be possessed of most of those attributes, are sincerely and intensely hostile to the so-called woman's movement. They do all they possibly can to check and hinder her advance. They give also very plausible reasons why woman should not go beyond her "sphere" determined by natural instincts, traditional and universal custom, etc. And yet, whether or not men's claims and protests are fair, just and expedient, the fact is that they are being respectfully ignored.

Within the last century woman has almost revolutionized society as far as it concerns herself individually. As late as 1789 the situation of woman in France reaffirmed the triumph of the traditional idea of her inferiority and the necessary subordination. Rich or poor, women were equally removed from all public life, equally deprived of all the means to cultivate their intelligence. Those who had to earn their livelihood found it impossible because of their ignorance. In England, the publication of the "Vindication of the Rights of Woman" (I792) brought upon the author "torrents of the vilest abuse." She was "denounced as a social outcast." "A philosophizing serpent," Horace Walpole politely called her. In the United States " up to 1848 the condition of married women under the law was nearly as degraded as that of the slave on the plantation?"'s To-day, the industrial, educational, professional, social, legal, every

2 Bebel: "Woman in the Past, Present and Future," p. 40.

'Chauvin, Jeanne: "Les Professions Acessibles aux Femmes," p. 188. 
one except the political, status of woman in those countries, is surprisingly high.

This great and rapid change cannot of course be accounted for by any single reason. Ages of human experience in theory and practice were necessary to enable both men and women not only to develop, but also to accept, the new condition. As in all other movements in human history the various influences and causes leading to a great social upheaval combine ultimately into one great force or principle which becomes the moving spirit in transforming an entire social system, so in the woman's movement the same law prevailed. Woman has early learned "to labor and to wait." But when the time had come for the recognition of the "feminine element" in the progress of civilization, women without concert of action, unknown to each other in every civilized country began, directly or indirectly, to demand a broader sphere, direct representation in society and the State. Lady Montague, Abigail Smith Adams, Mary Wolstoncraft, Harriet Martineau, Mme. Stael, Mme. Rolland, George Sand, Mme. D'Herricourt, Margaret Fuller, Elizabeth C. Stanton and others, in as many different ways, demanded the same thing. Aware of the necessity and the rightfulness of this demand woman has taken her "cause" in her own hands. And, whether or not men approve of it, whether or not her personal happiness is thereby increased, woman is bound to demand her "rights" and public opinion must sanction it. The condition in the modern organization of society makes it unavoidable.

\section{Conditions Favoring a Rise in Woman's Status.}

The argument for a woman's "sphere" may continue to be advocated by a certain type of men and women, too, but the question itself becomes less important as society conceives its raison d'etre to be neither military nor religious nor any other purpose but the well-being of its constituent, individual members. In a democratic society of this kind, where individuals have their choice in selecting vocations and the power to determine social values, they will naturally demand and receive their desired place in society. We see this idea realizing itself in the growing demands and gains of men since they became independent individuals, instead of being the property of or belonging to a state, an individual or a group of individuals. As 
long as men fought or worked for a chief, a king, an emperor, a lord on earth or served professionally a King in Heaven, they also stood in successive grades of subordination. For it was not society including themselves that determined men's position in the world. "L'etat, c'est moi" is the well-known motto of kings, and the same is carried out in the hierarchy of the Church. "By the grace of the Lord, the King, is a man high or low." Similar was the case of woman, but, of course, in a more complex form, since she was a subject's subject as well as an object of his emotions. As̀ long as the father or husband was the sole employer there could be no question of social remuneration. A woman worked for a private man who paid her "in kind," according to the dictates of his caprice, "finer sentiments," or reasonableness. There was practically no society or state for her apart from the man she happened to belong to. She did not work for society and, therefore, had no place in it, except as a man's property or protegé. In the exceptional cases, where she was supposed to serve the State, as in Sparta and in Plato's Republic, she was given a very high position.

But as soon as woman entered the factory, she became not only a social producer, but also an independent worker; $i$. $e$., her work had to be paid for at a definite rate, otherwise she could leave one employer for another. She now came into contact, moreover, with a new order of man, the strange employer who was emotionally indifferent to her, who had no claims over her, either as father, husband, or master, except as a wage-payer. He had no special reason to suppress or subject her. Individual skill had to be acknow1edged. Of course he met a very humble, submissive, ignorant, nonresisting creature and he took full advantage of these "feminine virtues" in cutting down her wages to the lowest point possible. "The mass of women had neither power nor wish to protest, and thus the few traces we find of their earliest connection with labor show us that they accepted a bare subsistence as all to which they were entitled, and were grateful if they escaped the beating which the lower order of Englishmen still regards it as his right to give!"s The employers' cruel treatment of women and their followers, the children, the conflict between the employers and the workingmen over

Johnson's Cyclopedia: p. 612.

s Campbell. Helen: "Women Wage-Earners," p. 52

[346] 
woman's employment and the fact that women were now social producers forced society to interfere in their behalf by means of legislation.

On the other hand, since the Industrial Revolution has taken place, the State, in the progressive countries, is ever more assuming the characteristics of an industrial organization. We may call it a limited monarchy, a republic or a political democracy; but its essential, its dominant interests are industry, and its concomitants, trade and commerce on an international scale. In their external relations the leading modern States are bent upon extending their economic activities through treaty right and acquisition of territory as markets. Internally their legislatures are largely busying themselves with the adjustment or the regulation of economic interests. "The past twenty-five years have been a period of incessant activity by legislatures and courts in prescribing the duties and limiting the powers and privileges of railway and express companies, telegraph companies, industrial combinations and trusts." The warrior and the clergyman are still present. But military force is a last resort, when other diplomatic means fail to secure commercial privileges; whereas, the Church, incorporated religion, is a private affair which may or may not be supported by individuals or groups of individuals. The captain of industry and the ethical teacher are gradually taking the place of the soldier and the theological teacher, respectively. Both have a place for woman's activity. One has given her a chance to become economically independent, the other, the moral motive "that makes for largeness of conscious life," the belief "that many things can be made better than they are at present and that life in many ways can be made more desirable."

The conditions in modern society favorable to a rise of woman's status are chiefly these: the opportunities for economic independence and direct service to society; the chances that man, the educator, the employer, and the legislator, may judge her rationally instead of emotionally as heretofore the father and the husband did; the decreasing importance of man as a military power, thus in a sense equalizing the social value of men and women; and the modern ethics advocating an increase of human happiness in this world rather than in some other one. Here woman is specially fit to do something.

"Prof. Giddings: "Democracy and Empire." p. 108. 


\section{Industrial Activity of Women.}

Economic writers generally explain woman's entrance into industry as a "wonder" of the age. Machinery, necessity, starvation or its extreme opposite "love of luxury" are given as chief causes. The fact that woman is only following her old pursuits while sharing in the general expansion of industry is rarely if ever, emphasized. She is regarded as usurping man's place, whereas in reality " the spirit of the living creature in the wheels of machinery is the genius of industrialism originated and fostered by women." 7 What this industrial age has effected is not woman's entrance into industry, but the social recognition that woman is an independent, economic factor as distinguished from a domestic worker. Writes Carroll D. Wright: "It cannot be said that women and children constituted an economic factor during the colonial days. Their labor was not in demand except in a domestic sense, to any great extent." "But their (women's) more extended employment as independent wageworkers dates practically from the period between 1815 to 1830 . They followed the textile industries from the household into the factories and the consolidation of industry in large establishments instead of small individual shops, broadened the field and gave women opportunities of entering independently in the gainful pursuits * * * which they gladly embraced." 9 Under the new conditions, "it is evident," says John A. Hobson, "that many forces are at work which tend to equalize the productivity of men and women in industry, the evolution of machinery adapted to the weaker physique of women; the breakdown of customs excluding women from many occupations; the growth of restrictions upon male adult labor with regard to their working day, etc., correspondent with those placed upon women; improved mobility of woman's labor by cheaper and more facile transport in large cities; the recognition of a growing number of women that matrimony is not the only livelihood open to them, but that an industrial life is preferable and possible."10

The proof of the economic value of women's industrial productivity is undoubtedly given by the fact that their numbers in all industries are steadily increasing. If their work did not pay, em-

7 Mason, Otis: "Woman's Share in Primitive Culture," p. 4.

- Wright, Carroll D.: "Industrial Evolution of the United States," p. 200.

Wright: p. 202.

10 Hobson: "Evolution of Modern Capitalism," p. 304. 
ployers would certainly not admit them. In England, according to Mr. Hobson, during the half century $184 \mathrm{I}$ and $\mathrm{I} 89 \mathrm{I}$, the number of women engaged in manufactures has increased by 22 I per cent., while that of men increased by 53 per cent. "But the movement," he adds, "is by no means peculiar to the textile and dress industries which may appear specially adapted to the faculties of women. Wherever women have got a firm footing in a manufacture a similar movement is traceable; the relative rate of increase in the employment of women exceeds that of men, even where the numbers of the latter do not show an absolute decline. Such industries are, wood furniture and carriages; painting and bookbinding; paper, floorcloths, feathers, leather, glues; food, drink, smoking ; earthenware, machinery, tools. Women have also obtained employment in connection with other industries which are still in the main 'male' industries, and in which no women or very few were engaged in $184 \mathrm{I}$. Such are fuel, gas, chemicals; watches, instruments, toys. The only group of machine industries in which their numbers have not increased more rapidly than those of men since $185 \mathrm{I}$ are the metal industries. Over some of these, however, they are obtaining an increased hold. In the more mechanical portions of the growing 'cycle' of industry, hollow-ware and in certain departments of the watch-making trade they are ousting male labor, executing with machinery the work formerly done by male hand-workers." 11

The following table, taken from the Twelfth Census of the United States, shows the general progress of American women in all gainful occupations, since 1880 , as compared with that of men:

\begin{tabular}{|c|c|c|c|c|c|c|}
\hline & \multicolumn{2}{|l|}{1900} & \multicolumn{2}{|l|}{1890} & \multicolumn{2}{|l|}{1880} \\
\hline & Number & $\begin{array}{c}\text { Per } \\
\text { Cent }\end{array}$ & Number & $\begin{array}{l}\text { Per } \\
\text { Cent }\end{array}$ & Number & $\begin{array}{l}\text { Per } \\
\text { Cent }\end{array}$ \\
\hline 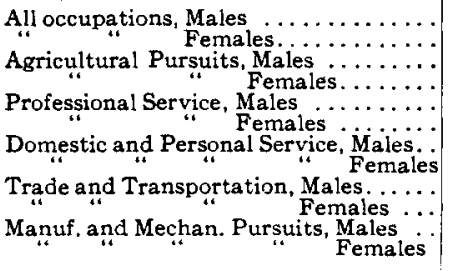 & $\begin{array}{r}23,754,205 \\
5,319,912 \\
9,404,429 \\
977,336 \\
828,163 \\
430,576 \\
3,485,208 \\
2,095,449 \\
4,263,617 \\
503,397 \\
5,772,788 \\
1,313,204\end{array}$ & \begin{tabular}{|r|}
100 \\
100 \\
39.6 \\
18.4 \\
3.5 \\
8.1 \\
14.7 \\
39.4 \\
17.9 \\
9.4 \\
24.3 \\
24.7
\end{tabular} & $\begin{array}{r}18,821,090 \\
3,914,571 \\
7,887,042 \\
678,884 \\
632,646 \\
311,687 \\
2,553,161 \\
1,667,651 \\
3,097,701 \\
2288.421 \\
4,650,540 \\
1,027,928\end{array}$ & $\begin{array}{r}100 \\
100 \\
41.9 \\
17.3 \\
3.4 \\
8.0 \\
13.6 \\
42.6 \\
16.4 \\
5.8 \\
24.7 \\
26.3\end{array}$ & $\begin{array}{r}14,744,942 \\
2,647,157 \\
7,119,365 \\
594,510 \\
425,947 \\
177,255 \\
2,242,309 \\
1,181,506 \\
1,803,629 \\
62,852 \\
3,153,692 \\
631,034\end{array}$ & $\begin{array}{r}100 \\
100 \\
48.3 \\
22.5 \\
2.9 \\
6.7 \\
15.2 \\
44.6 \\
12.2 \\
2.4 \\
21.4 \\
23.8\end{array}$ \\
\hline
\end{tabular}

"Hobson, p. 295. 
In the least "female" occupation, "trade and transportation," the percentage for women has increased from $2.4 \mathrm{vs}$. 12.2 for men in I 880 to 9.4 vs. 17.9 for men in 1900 ; while the percentage in the leading female occupation, "domestic and personal service," is gradually decreasing from 44.6 in 1880 to 42.6 in 1890 , to 39.4 in 1900 . "All the industries in the United States, and their variety is practically unlimited, were assigned," says Mr. Wright, "to one of three hundred and sixty-nine groups at the Census of 1890 . An examination of the totals of these groups discloses the fact that in only nine of them are nowomen and children employed. Their employment, therefore, either as clerks, operatives or apprentices, may be considered universal. The apparent number of vocations in which women cannot engage is constantly diminishing and is now relatively very small." 12 This statement may be compared with one made in 1840 by Harriet Martineau, who found "only seven employments open to women: teaching, needlework, keeping boarders, working in cotton mills, type-setting, bookbinding and domestic service." 13

\section{Women's Wages.}

The growing appreciation of woman's work is indicated by a relative rise in wages. "The greatest percentage of gain in average wages in the cotton industries is in favor of the female employees." 14 The average weekly earnings in cotton factories of New England for women in $183 \mathrm{I}$ ranged from $\$ 2.20$ to $\$ 2.60$, and for men, from $\$ 4.50$ to $\$ 7.00$. For women in 1880 it was $\$ 6.37$, and for men, $\$ 9.05$. In the same industry for the entire United States the average weekly wage for women in 1890 was $\$ 5.53$, ranging from $\$ 3.21$ to $\$ 6,42$. For men in 1890 it was $\$ 7.75$, ranging from $\$ 5.17$ to $\$ 10.44$. "In 183 I men's wage was twice as great as women's; in I880 it was less than one-third greater. Between 1831 and 1880 men's wages had increased 38 per cent.; woman's, 149 per cent. * * * A careful examination of the actual earnings of women discloses the fact that in many industries their average earnings equal or exceed the earnings of men. This is especially true of the piece workers." 15 In general, however, it must be said that woman's wages as compared with man's is considerably lcwer. But this is easily explained, when we

12 Wright, p. 209.

18 Ibid., p. 202 .

34 lbid., p. 210

is Ibid., p. 210 . 
consider the fact that "she has stepped out of industrial subjection and come into the industrial system as an entirely new economic factor. If there were no other reasons this alone would be sufficient to keep her wages low and prevent their very rapid increase." 18

\section{Women in Labor Organizations.}

Professor Mason, in his book on "Woman's Share in Primitive Culture," devotes a chapter to woman as a Jack-at-all-Trades, and remarks that in the entire course of human history the combination of abilities in one woman stands in sharp contrast with the co-operation of many individuals at one duty or activity among men. "In co-operation," he says, "women have always been weak. There are few duties that they have in common. Even as beasts of burden they seldom worked in pairs." 17 Unless we can realize what must be the effect of centuries of isolated work we can hardly explain the illsuccess of women's trade-unionism, nor appreciate the progress already made by women in co-operating with one another for various other purposes. "In industry women, as a class, are just beginning to understand the power and the force which come from organization, "18 says Mr. Wright. This is true; but woman's entrance into labor-unions took place before she became conscious of her "class."

The employers' persistence in keeping women at the trades, wherever wages could be saved, and the workingmen's conviction that they must either leave their trades or admit women to their unions was the real cause of women's first connection with unionism. There was, of course, a strong opposition. "The eighteenth century trade clubs of hatters, basketmakers or compositors would have instantly struck against any attempt to put a woman to any part of their craft." The intensity of resentment and abhorrence with which the average workingman regards the idea of woman entering his trade equals that displayed by the medical practitioner of the last generation. "19 The Lancashire weavers alone never made any sex distinctions. The various organizations of weavers have from the introduction of the power-loom included women on the same terms as men.

16 Wright, p. 212.

17 Mason, p. 160.

18 Wright, p. 213.

10 Webb, p. 496. ("Industrial Democracy.") 
The typical status of woman in the "male" occupations may be illustrated by the following resolution passed by the London society of compositors, I 886: "While strongly of opinion that women are not physically capable of performing the duties of a compositor, this conference recommends their admission to membership of the various Typographical Unions upon the same conditions as journeymen, provided always the females are paid strictly in accordance with scale."20 The standard rate practically excludes sex competition, while it does not debar a woman from a man's work, provided she wins her way "by capacity not by underbidding."

In Germany, the workingmen for a long time believed that the employment of women could be restricted. "But, in spite of all efforts of restriction, the employment of women increased constantly until five and a half millions, according to the Census of 1882 , were wage-earners. *** Then only did the workingmen realize that women workers were no longer a factor to be neglected, and that equal duties towards society gave them equal rights. At their Parteitag or Annual Congress held at Halle in 1890 , the Social Democrats therefore passed a resolution demanding the full equality of the sexes in the State and society; and the next year at Brussels, the International Socialists' Congress adopted the same resolution unanimously. After 1892 women were permitted to choose delegates to the Annual Congress and now the members of the workingwomen's association are an integral factor of the Social Democratic Party." 21

In the United States, the Knights of Labor and the Granger associations of the Western Farmers have been very liberal in the admission of women. The Western Farmers formulated (1870) "a principle" that no Grange should be organized or exist without women. The more conservative men, too, began about $\mathrm{I} 884$ to receive women in their unions. The rapid advance here made is evident in the United Garment Workers' Union. “In its establishment (1891) women bore no part, either directly or indirectly," says Miss Hurd. "In April, 1902, the union was composed of 179 local bodies, of which 83 admitted men only, while 96 were made up either exclusively of women or of both men and women." 22 Their number of delegates at the conventions increased from 2 out of 53 in 1894 to 18 out of 56

${ }^{20} \mathrm{Webb}$, p. 500. 21 Russell, Alys.: "Social Democracy and the Woman Question in Germany," pp. 187-8.
22 Hurd, p. 168. 
in 1900 and 23 out of 88 in I90 I. ${ }^{23}$ "An interesting phase of the changing attitude of women toward unions is revealed," says John Mitchell, "by the action of the Chicago Federation of Teachers. The teachers of Chicago, recognizing that they were wage-earners and realizing the similarity of their aims and ideals with those of the great body of trade-unionists, threw their fortunes in with their fellow-workers and became affiliated with the Chicago Federation of Labor." That woman as a factor in organized labor is considered important, the words of the most prominent labor-leader of to-day amply testifies: "The future will undoubtedly show a vast strengthening of the labor movement through the compact organization of the women employed in American industries."24

New York City

SOPHIE YUDELSON

${ }^{28} \mathrm{Hurd}$, p. 169.

24 Mitchell: "Organized Labor," p. 135. 